\title{
Hepatitis B and Delta: clinical aspects of patients in the Brazilian Western Amazonia
}

\author{
Hepatite B e Delta: aspectos clínicos de pacientes na Amazônia Ocidental brasileira \\ Hepatitis B y Delta: aspectos clínicos de pacientes en el Amazonas brasileño Occidental
}

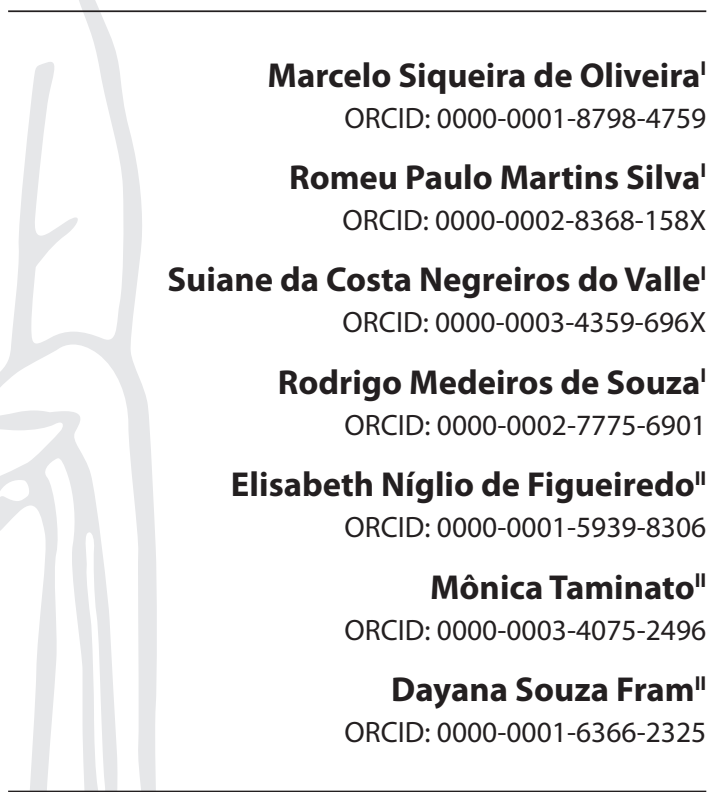

'Universidade Federal do Acre. Cruzeiro do Sul, Acre, Brazil. "Universidade Federal de São Paulo. São Paulo, São Paulo, Brazil.

How to cite this article: Oliveira MS, Silva RPM, Valle SCN, Souza RM, Figueiredo EN, Taminato M, et al. Hepatitis B and Delta: clinical aspects of patients in the Brazilian Western Amazonia.

Rev Bras Enferm. 2019;72(5):1265-70. doi: http://dx.doi.org/10.1590/0034-7167-2018-0100

Corresponding Author:

Marcelo Siqueira de Oliveira E-mail: marcelo.oliveira@ufac.br

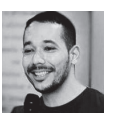

Submission: $02-28-2018$

Approval: 08-13-2018

\section{ABSTRACT}

Objective: to analyze clinical, serological, biochemical and hematological aspects in patients infected with the hepatitis B (HBV) and Delta (HDV) viruses. Method: cross-sectional, descriptive and retrospective study, performed with patients chronically infected with $\mathrm{HBV}$ and superinfected with HDV. Results: among the 112 patients selected, $74 \%$ were monoinfected with HBV (Group HBV) and 26\% were superinfected with HDV (Group HBV+HDV). There was no difference in gender distribution. The average age was 36 years with standard deviation of \pm 12 years. The symptoms and signs presented a higher proportion in Group HBV+HDV $(p=0.001)$. In both groups, most patients had non-reactive $\mathrm{AgHBe}$. The records of biochemical and hematologic changes showed highest proportion in Group VHB+VHD Group $(p<0.05)$. Conclusion: the study found that patients were in clinical stages of the disease different from those in the initial examination for monitoring their chronic condition. The clinical profile suggests greater severity of liver disease among the patients superinfected with HDV. Descriptors: Hepatitis B; Hepatitis D; Precision Medicine; Prognosis; Public Health.

\section{RESUMO}

Objetivo: Analisar aspectos clínicos, sorológicos, bioquímicos e hematológicos entre pacientes infectados por vírus das hepatites B (VHB) e Delta (VHD). Método: Estudo transversal, descritivo, retrospectivo, realizado com pacientes cronicamente infectados por VHB e superinfectados por VHD. Resultados: Entre os 112 pacientes selecionados, $74 \%$ estavam monoinfectados por VHB (Grupo VHB) e $26 \%$ superinfectados por VHD (Grupo VHB+VHD). Não houve diferença na distribuição por gênero. A idade média foi de 36 anos, com desvio padrão de \pm 12 anos. Os sintomas e sinais apresentaram maior proporção no grupo $\mathrm{VHB}+\mathrm{VHD}(p=0,001)$. Para ambos os grupos, a maioria dos pacientes estava com $\mathrm{AgHBe}$ não reagente. $\mathrm{O}$ registro de alterações bioquímicas $\mathrm{e}$ hematológicas apresentou maior proporção no grupo VHB+VHD $(p<0,05)$. Conclusão: $\mathrm{O}$ estudo revelou que os pacientes estavam em diferentes estágios clínicos da doença na consulta inicial para acompanhamento de condição crônica. O perfil clínico sugere maior gravidade da doença hepática entre os pacientes superinfectados por VHD. Descritores: Hepatite B; Hepatite D; Perfil de Saúde; Prognóstico; Saúde Pública.

\section{RESUMEN}

Objetivo: Analizar los aspectos clínicos, serológicos, bioquímicos y hematológicos de pacientes infectados por el virus de las hepatitis B (VHB) y Delta (VHD). Método: Se trata de un estudio transversal, descriptivo, retrospectivo, realizado entre pacientes crónicos infectados de VHB y sobre infectados de VHD. Resultados: Entre los 112 pacientes seleccionados, el $74 \%$ estaba mono infectado por VHB (Grupo VHB) y el $26 \%$, sobre infectado por VHD (Grupo VHB+VHD). No se encontró diferencia en la distribución por género. La edad promedio era 36 años, con desviación típica de \pm 12 años. Los síntomas y signos sobresalían en mayor proporción en el grupo VHB+VHD $(p=0,001)$. Para ambos grupos, la mayoría de los pacientes estaba con AgHBe no reactivo. El registro de alteraciones bioquímicas y hematológicas atribuyó proporción más grande al grupo VHB+VHD $(p<0,05)$. Conclusión: El estudio demostró que los pacientes, en la consulta inicial para el seguimiento de la condición crónica, estaban en diferentes estadios clínicos de la enfermedad. El perfil clínico sugiere que la gravedad de la enfermedad hepática es mayor entre pacientes sobre infectados de VHD.

Descriptores: Hepatitis B; Hepatitis D; Perfil de Salud; Pronóstico; Salud Pública. 


\section{INTRODUCTION}

Chronic hepatitis B (HBV) associated with Delta virus infection (HDV) represents an important public health problem ${ }^{(1-2)}$. The number of HBV chronic carriers is estimated at 240 to 350 million $^{(3-4)}$, and, from these, 15 to 20 million are coinfected or superinfected with $\mathrm{HDV}^{(5)}$.

The physio-pathological relation involving the virus is directly related with the structure of $\mathrm{HBV}$. Belonging to the hepadnaviridae family with tropism for liver cells, and with humans as its natural host $^{(2)}$, HBV has a genome composed by a deoxyribonucleic acid (DNA) and a set of proteins that forms specific antigens, with emphasis to: the surface antigen (HBsAg), used as diagnostic reference; the $e$ antigen ( $\mathrm{HBeAg}$ ), which is related to the viral replication activity; and the core antigen ( $\mathrm{HBcAg})$, which, through the immunoglobulins $M$ and $G$ ( $\lg M$ e $\lg G)$, indicates infectionrelated temporality ${ }^{(6-7)}$. HDV, in view of the complex structure of $\mathrm{HBV}$, consists of a single open reading frame of ribonucleic acid (RNA) and needs HBsAg to infect cells and assemble new viral structures ${ }^{(8-9)}$.

The HBsAg, $\mathrm{HBeAg}$ and $\mathrm{HbcAg}$ induce the production of correlated antibodies: anti-HBs; anti-HBe and anti-HBc. The HDV genome induces the production of anti-HD ${ }^{(10)}$. Antigens and antibodies are used, through a serology technique, as reference for prophylaxis effects, diagnosis and therapeutic follow-up ${ }^{(2,7,10)}$.

Concerning diagnosis, HBV infection is considered chronic when the patient presents reactive $\mathrm{HBsAg}$ for more than six months, with viral load (HBV-DNA) $>20,000 \mathrm{UI} / \mathrm{ml}$ with reactive $\mathrm{HBeAg}$ or $>2,000 \mathrm{UI} / \mathrm{ml}$ with non-reactive $\mathrm{HBeAg}^{(10-11)}$. Within this HBV aspect, HDV infection is considered coinfection when it occurs in the acute phase, and superinfection when it occurs in the chronic phase ${ }^{(5,12)}$.

Biochemical evaluation is a complementary element of great importance in the diagnosis and in the therapeutic management of patients. Monitoring of alanine aminotransferase (ALT) and aspartate aminotransferase (AST) signals the presence of an active liver disease, while examinations such as serum bilirubin and creatinine assist in the monitoring of the hepatic and renal function, respectively. The hematologic evaluation is also of great importance during the course of the disease's natural history, as it offers parameters related to the general condition of patients ${ }^{(10,13)}$.

However, the society-ecosystem interaction also represents an important aspect in characterizing and understanding the pathological process, especially when specific geographic spaces are considered, such as the Amazon region, where the epidemiological analysis of endemic and epidemic process should be recorded in a particular way in order to define the "disease landscape", that is, a more cohesive vision of local determinants ${ }^{(14)}$, which is the case of hepatitis B and Delta in the Brazilian Western Amazonia.

In addition, aspects regarding the structure of health services, especially when paid-up public policies are taken into consideration, reveal a geographical space marked by social inequalities, in a vast area of low population density, difficult to access and with technological precariousness that limit care complexity ${ }^{(15)}$.

In this way, in face of the exposed considerations, this research aims to contribute with the analysis of clinical, serological, biochemical and hematological aspects related to viral hepatitis $B$ and Delta in the context of the Brazilian western Amazonia, in order to favor a better clinical and epidemiological understanding of patients with this infection, to improve the diagnosis process, clinical management and care assistance.

\section{OBJECTIVE}

To analyze clinical, serological, biochemical and hematological aspects in patients infected by the hepatitis B (HBV) and Delta (HDV) viruses.

\section{METHOD}

\section{Ethical aspects}

This research was authorized by the technical direction of the Regional Hospital of Juruá and approved by the Research Ethics Committee of the Federal University of São Paulo - UNIFESP.

\section{Study design, location and period}

Cross-sectional, descriptive, retrospective study performed with outpatients chronically infected by the hepatitis B virus (Group $\mathrm{HBV}$ ) and superinfected by the Delta virus (Group VHD+VHD).

The study was performed in the municipality of Cruzeiro do Sul, Acre, Brazilian Western Amazonia, in the Hepatology and Infectiology ward of the Regional Hospital of Juruá (HRJ - Hospital Regional do Juruá), a health reference center of the Alto Rio Juruá regional, considering the period between January 2014 and December 2016.

\section{Study sample (inclusion and exclusion criteria)}

The study population was composed of patients infected with the hepatitis B virus and patients superinfected with the Delta virus, divided in two groups (Group HBV and Group HBV+HDV).

- Inclusion criteria: in this study, all patients who met the eligibility criteria of the research were included, aged 18 years old or over, chronically infected with HBV and superinfected with HDV.

- Exclusion criteria: patients with the following conditions were excluded: infection with hepatitis C virus (HCV) and human immunodeficiency virus (HIV), autoimmune disease, malignant neoplasm not related with infectious liver disease, chronic unbalanced conditions such as diabetes, kidney and heart failure, pregnant women and those who had no record of routine examinations for screening or initial clinical management on patient records.

\section{Study protocol}

Data were collected through consulting chart records. In the initial approach, 542 patients' records were pre-selected with diagnosis of HBV and HBV+HDV infection. After applying the eligibility criteria proposed in this research, 430 records were excluded: 176 were pregnant women, 135 did not have routine examination records, 36 were minors $(<18)$ and 83 had a diagnosis of another associated chronic condition. The sample selected for the study was of 112 patients. 
Observed variables: demographic aspects: gender (male or female), age (full years); clinical aspects: symptoms (asthenia, anorexia, nausea, vomiting, fever, joint pain, muscle aches, abdominal pain, headache, diarrhea, acholia, choluria, pruritus, hematemesis, melena and weight loss) and signs (edema, ascites, jaundice, spider angiomas, palmar erythema, collateral circulation, muscle atrophy, alopecia, gynecomastia and testicular atrophy); serological aspects: qualitative result of $\mathrm{HBsAg}, \mathrm{HBeAg}$, anti-HBc - IgM/lgG, Anti-HBe, Anti-HBs e Anti-HDV; biochemical aspects: quantitative and categorical result of prothrombin time in international normalized ratio (PT/INR) (Reference value (RV): 0.80 to $1.20-11$ to 13 seconds $=100 \%$, alanine aminotransferase (ALT) (RV: 10 to $41 \mathrm{U} / \mathrm{l}$ ), aspartate aminotransferase (AST) (RV: 7 to $40 \mathrm{U} / \mathrm{l}$ ), serum bilirubin (RV: 0.30 to $1.20 \mathrm{mg} / \mathrm{dl}$ ), creatinine (RV: 0.40 to $1.30 \mathrm{mg} / \mathrm{dl}$ ); hematological aspects: hematocrit (RV: women 35-47 and men 40-54\%), erythrocytes (RV: women 4.05.6 and men 4.5-6.5 million $/ \mathrm{mm}^{3}$ ), hemoglobin (women 12-16.6 and men $13.5-18 \mathrm{~g} / 100 \mathrm{ml}$ ), lymphocytes (RV: $20-40 \%)$ e platelets (VR:150,000 to $400,000 \mu l$ ).

\section{Results analysis and statistics}

The data were tabulated in Microsoft Office Excel 2013 and the statistical analysis was performed using Stata 14 (StataCorp, College Station, USA, 2015) software and GraphPad Prism 6.0 (GraphPad Software, La Jolla, USA, 2012) software. For result expression, the qualitative variables were described through distribution of absolute and relative frequencies, while the quantitative one was described through minimum and maximum values, average, median and standard deviation. To analyze categorical variables, Fisher's exact test was used. Throughout the analysis, a significance level of $5 \%(p<0.05)$ was used.

\section{RESULTS}

Of the 112 patients who composed the study sample, $74.1 \%$ $(\mathrm{n}=83$ ) were monoinfected with B virus (Group HBV), and $25.89 \%$ $(n=29)$ were superinfected with Delta virus (Group HBV+HDV). Regarding the gender variable, for the whole sample, $46.4 \%$ were men and 53.6\% were women. When the groups were compared, it was observed that, among the patients from group HBV, 49.4\% were male and 50\% were female. As for Group HBV+HDV, $37.9 \%$ patients were male and $62.1 \%$ were female. The statistical analysis of the gender variable showed no significant difference between the observed groups $(p=0.387)$.

Regarding age, for the whole variable, the overall average was 36 years, with a standard deviation of \pm 12 years, without any statistically significant difference between the studied groups $(\mathrm{p}=0.867)$.

Tables 1 and 2 show distribution of signs and symptoms observed, respectively. Of the 112 patients who composed the study sample, 5.4\% had no information in their medical records regarding symptoms and signs. For statistical analysis of these variables, $n=106$ was considered and, of these, $74.5 \%(n=79)$ was from Group HBV and 25.5\% $(n=27)$ from Group HBV+HDV.

Regarding the general record of clinical symptoms, a higher proportion was observed in Group HBV+HDV, showing a statistically significant difference between the observed groups $(p=0.001)$. Among the specific symptoms recorded, there was statistically significant difference for abdominal pain $(p=0.007)$ and fever $(p=0.002)$, both with greater frequency in Group HBV+HDV.

Table 1 - Distribution of clinical symptoms among patients with chronic hepatitis B (Group HBV) and superinfected with Delta virus (Group HBV+HDV), Cruzeiro do Sul, Acre, Brazil, 2014 to 2016

\begin{tabular}{llcccc}
\hline & \multicolumn{5}{c}{ Groups } \\
& HBV & (n=79) & HBV+HDV & (n=27) & \\
& $\mathbf{n}$ & \% & $\mathbf{n}$ & $\%$ & $\mathbf{p}^{*}$ \\
\hline Symptoms (Overall) & 38 & 48.0 & 23 & 85.2 & 0.001 \\
Asthenia & 13 & 16.5 & 07 & 25.9 & 0.392 \\
Anorexia & 04 & 5.16 & 02 & 7.4 & 0.643 \\
Nausea & 15 & 19.0 & 06 & 22.2 & 0.781 \\
Vomiting & 06 & 7.6 & 02 & 7.4 & 1.000 \\
Abdominal pain & 18 & 22.8 & 14 & 51.9 & 0.007 \\
Fever & 08 & 10.1 & 09 & 33.3 & 0.012 \\
Arthralgia & 07 & 8.9 & 05 & 18.5 & 0.177 \\
Myalgia & 11 & 13.9 & 08 & 29.6 & 0.083 \\
Diarrhea & 04 & 5.1 & 02 & 7.4 & 0.643 \\
Acholia & 00 & 0.0 & 01 & 3.7 & 0.254 \\
Choluria & 01 & 1.3 & 01 & 3.7 & 0.446 \\
Pruritus & 01 & 1.3 & 00 & 0.0 & 1.000 \\
Weight loss & 00 & 0.0 & 01 & 3.7 & 0.254 \\
\hline
\end{tabular}

Note: *Fisher's exact test $(p<0.05)$.

Table 2 - Distribution of clinical signs among patients with chronic hepatitis B (Group HBV) and superinfected with Delta virus (Group HBV+HDV), Cruzeiro do Sul, Acre, Brazil, 2014 to 2016

\begin{tabular}{|c|c|c|c|c|c|}
\hline \multicolumn{6}{|c|}{ Groups } \\
\hline & \multicolumn{2}{|c|}{ HBV $(n=79)$} & \multicolumn{2}{|c|}{ HBV+HDV $(n=27)$} & \multirow[b]{2}{*}{${ }^{*} \mathbf{p}$} \\
\hline & $\mathbf{n}$ & $\%$ & $\mathbf{n}$ & $\%$ & \\
\hline Signs (Overall) & 02 & 2.5 & 10 & 37.0 & $<0.001$ \\
\hline Edema & 01 & 1.3 & 06 & 22.2 & 0.001 \\
\hline Ascites & 02 & 2.5 & 05 & 18.5 & 0.011 \\
\hline Jaundice & 02 & 2.5 & 04 & 14.8 & 0.036 \\
\hline Alopecia & 00 & 0.0 & 01 & 3.7 & 0.255 \\
\hline
\end{tabular}

Note: *Fisher's exact test $(p<0.05)$.

When considering the sum of clinical signs observed in this study, Table 2, a statistically significant difference was verified between the studied groups $(p<0.001)$, with greater proportion in Group HBV+HDV. In the specific signs observed, there was also a record of statistically significant difference for the variables: edema $(p=0.001)$, ascites $(p=0.011)$ and jaundice $(p=0.036)$.

Table 3 shows details of the serological profile between the groups studied.

When the qualitative results of $\mathrm{HBeAg}$ and Anti-HBe were assessed, it was found that, for both Group HBV (83.1\%) and for Group HBV+HDV (72.4\%), there was a higher relative frequency of patients with reactive Anti-HBe, compared to a variation between the groups of $7.2 \%$ to $10.3 \%$ records of reactive HBeAg. For both groups, the majority of patients showed a reactive result for the presence of the core antibody (Anti-HBc) with lgG. The Anti-HBs testing showed predominantly no response to HBsAg. Serological tests had no statistically significant difference between the studied groups. 
Table 3 - Qualitative results of serology for hepatitis B and Delta among patients with chronic hepatitis B (Group HBV) and superinfected with Delta virus (Group HBV+HDV), Cruzeiro do Sul, Acre, Brazil, 2014 to 2016

\begin{tabular}{|c|c|c|c|c|c|c|c|c|c|c|c|c|c|}
\hline \multicolumn{14}{|c|}{ Groups } \\
\hline & & \multicolumn{4}{|c|}{ HBV $(n=83)$} & \multicolumn{8}{|c|}{ HBV+HDV $(n=29)$} \\
\hline & $(+)$ & $\%$ & $(-)$ & $\%$ & $\not \nexists$ & $\%$ & $(+)$ & $\%$ & $(-)$ & $\%$ & $\not \nexists$ & $\%$ & ${ }^{*} \mathbf{p}$ \\
\hline $\mathrm{HBsAg}$ & 83 & 100 & 0 & 0.0 & 0 & 0.0 & 29 & 100 & 0 & 0 & 0 & 0.0 & 1.000 \\
\hline $\mathrm{HBeAg}$ & 6 & 7.2 & 74 & 89.2 & 3 & 3.6 & 3 & 10.3 & 20 & 69.0 & 6 & 20.7 & 0.414 \\
\hline Anti-HBe & 69 & 83.1 & 10 & 12 & 4 & 5.0 & 21 & 72.4 & 4 & 13.8 & 4 & 13.8 & 0.739 \\
\hline Anti-HBC $c^{(l g G)}$ & 82 & 98.8 & 1 & 1.2 & 0 & 0 & 28 & 95.6 & 0 & 0.0 & 1 & 3.4 & 1.000 \\
\hline Anti-HBs & 2 & 2.4 & 80 & 96.4 & 1 & 1.2 & 1 & 3.4 & 28 & 95.6 & 0 & 0.0 & 1.000 \\
\hline Anti-HD & 0 & 0.0 & 83 & 100 & 0 & 0.0 & 29 & 100 & 0 & 0.0 & 0 & 0.0 & 1.000 \\
\hline
\end{tabular}

Table 4 - Results of biochemical texts among patients with chronic hepatitis B (Group HBV) and superinfected with Delta virus (Group HBV+HDV), Cruzeiro do Sul, Acre, Brazil, 2014 to 2016

\begin{tabular}{|c|c|c|c|c|c|c|c|c|c|}
\hline \multicolumn{10}{|c|}{ Groups } \\
\hline & \multicolumn{3}{|c|}{ HBV $(n=83)$} & \multicolumn{6}{|c|}{ HBV+HDV $(n=29)$} \\
\hline & Norma & $\%$ & High & $\%$ & Normal & $\%$ & High & $\%$ & p \\
\hline PT INR & 56 & 67.4 & 27 & 33 & 19 & 65.5 & 10 & 34 & 1.000 \\
\hline ALT & 63 & 75.9 & 20 & 24 & 12 & 41.3 & 17 & 59 & 0.001 \\
\hline AST & 64 & 77.1 & 19 & 23 & 15 & 51.7 & 14 & 48 & 0.017 \\
\hline Bilirubin & 78 & 93.9 & 5 & 6 & 21 & 72.4 & 8 & 28 & 0.004 \\
\hline Creatinine & 79 & 95.1 & 4 & 5 & 29 & 100 & 0 & 0 & 0.571 \\
\hline
\end{tabular}

Nota: *Fisher's exact test.

Table 5 - Hematological alterations among patients with chronic hepatitis B (Group HBV) and superinfected with Delta virus (Group HBV+HDV), Cruzeiro do Sul, Acre, Brazil, 2014 to 2016

\begin{tabular}{lccccc}
\hline \multirow{2}{*}{ Alterations } & \multicolumn{5}{c}{ Groups } \\
& HBV (n=83) & \multicolumn{2}{c}{ HBV+HDV (n=29) } & \\
& $\mathbf{n}$ & $\mathbf{\%}$ & $\mathbf{n}$ & $\mathbf{\%}$ & ${ }^{*} \mathbf{p}$ \\
\hline Anemia & 08 & 9.6 & 08 & 27.6 & 0.029 \\
Lymphopenia & $18^{\#}$ & 22.2 & 09 & 31.0 & 0.451 \\
Lymphocytosis & $07^{\#}$ & 8.6 & 04 & 13.8 & 0.476 \\
Thrombocytopenia & 17 & 20.5 & 15 & 51.7 & 0.003 \\
Thrombocytosis & 01 & 1.2 & 15 & 51.7 & $<\mathbf{0 . 0 0 1}$ \\
\hline Note: *Fisher's exact test; $\#$ =81. & & & & &
\end{tabular}

As for the assessment of biochemical analysis, patients from Group HBV+HDV showed a higher proportion in most tests with altered results, except for creatinine. For the PT/INR and creatinine variables, the contingency analysis did not show statistically significant difference between the studied groups. Regarding the ALT, AST and serum bilirubin variables, there was greater proportion in Group HBV+HDV with statistically significant difference.

Table 5 shows hematological alterations observed between the groups of studied patients.

As for the distribution of hematological alterations, Table 5, a statistically significant difference was observed for the variables anemia $(p=0.029)$, thrombocytopenia $(p=0.003)$ and thrombocytosis $(p=<0.001)$, all with greater proportion in group HBV+HDV. For the variables lymphopenia and lymphocytosis, 81 of the 83 selected patients from Group HBV showed information necessary for the analysis. For these two variables, no statistically significant difference was observed between the groups.

\section{DISCUSSION}

The patient sample showed a greater distribution of women for both studied groups, but there was no significant statistical difference. In Western Amazonia, records indicate a predominance of cases in male individuals, a pattern applicable to most endemic areas in the world ${ }^{(11,16)}$.

The average age of 36 years, with standard deviation of \pm 12 years, reveals a patient profile mostly formed by young adults. A result that converges with the age group evidenced in other studies performed in the same region ${ }^{(12,16-17)}$.

The record of symptoms is part of the need for a thorough evaluation among the infected, because patients can be asymptomatic for long periods even when they have a chronic disease ${ }^{(6,18)}$. Manifestations of symptoms more frequent in Group HBV+HDV can reflect a worse clinical condition induced by superinfection with HDV and are frequently reported in scientific literature ${ }^{(5,19)}$.

The observation of clinical signs such as edema, ascites and jaundice, indicators of active liver disease, with a significantly higher proportion for Group HBV+HDV, again suggests greater severity of the illness among the superinfected with $\operatorname{HDV}^{(1,5)}$. These signs are characteristic of advanced liver disease and reflect complications that require careful therapeutic management, due to the peculiarities inherent to each patient $\mathrm{t}^{(3,6,11)}$.

The serological profile shows that $26 \%$ patients were superinfected with HDV, converging with the expectation of $30 \%$ of associated infection for risk areas ${ }^{(5)}$. This percentage converges with the values found in areas of intermediate and high endemicity, such as the Mediterranean region, Central Africa, Middle East and $\mathrm{Asia}^{(20-21)}$. However, the estimate of superinfected patients may vary according to the community or applied methodological design. In a study conducted in another health unit in the same region, a percentage of $57 \%$ of patients coinfected or superinfected with HDV was observed ${ }^{(22)}$.

As for observations regarding the HBeAg qualitative profile and the presence of anti-HBe, there was no considerable variation between the groups, and the absolute majority of patients had reactive anti-HBe. Although the Brazilian Ministry of Health adopts HBeAg as one of the parameters to define chronic illness and to indicate drug treatment ${ }^{(10)}$, following guidelines from international consensus ${ }^{(23)}$, the use of these variables does not clinically distinguish patient groups with safety ${ }^{(24)}$. Even with the evaluation of the number of viral copies, studies show that, through the observation of $\mathrm{HBeAg}$, anti-HBe and viral load results, patients classified as out of criterion for drug treatment had active and progressive liver disease when subjected to histological evaluation ${ }^{(13,24-25)}$. As for the antibodies $\mathrm{C}$ and $\mathrm{S}$, the results confirmed a profile compatible with chronic condition of the disease investigated.

The study also described important biochemical markers of daily and protocol use in Brazil, indicated for complementary evaluation of patients' clinical state ${ }^{(10)}$. In the whole sample, $33 \%$ of the patients showed an altered PT/INR, without significant differences between the groups studied. The PT/INR, besides evaluating the blood coagulation factor, also assists in estimating risks for acute or chronic liver failure ${ }^{(26)}$. 
ALT and AST levels indicated greater proportion among patients superinfected with HDV.These enzymes, especially ALT, are considered severity markers of liver disease and of response to the treatment. Although they represent an important instrument for diagnostic research, the ALT and AST enzymes suffer limitations related to variables such as age, weight and concomitant liver disease ${ }^{(27)}$.

Another important biochemical aspect lies in observing serum levels of bilirubin and creatine. As for the bilirubin, the research result showed a significant difference between the studied groups, with greater proportion among the superinfected with HDV. Bilirubin is a marker of liver function and also an important variable for prognostic evaluation ${ }^{(28)}$. Creatine is an important marker to assess kidney function and is also an essential tool for estimating the prognosis ${ }^{(28)}$, and, to this variable, the proportion between the groups showed no significant difference.

The record of hematological alterations shows relevant aspects when one takes into consideration the fact that the studied patients were in initial approach for treatment and follow-up of chronic hepatitis B. The presence of alterations such as anemia, thrombocytopenia and thrombocytosis, with greater proportion between those superinfected with HDV, in addition to showing signs of severe chronic liver disease, can also prevent the adoption of initial therapeutic measures, especially regarding drug prescription ${ }^{(3,10,18,23)}$.

\section{CONCLUSION}

The study revealed that patients were in clinical stages of the chronic liver disease different from those in the initial examination for monitoring their chronic condition. The description of clinical, serological, biochemical and hematological aspects of the studied patients showed a clinical profile which indicated greater severity of liver disease among patients superinfected with HDV.

The initial profile of chronic patients from tests feasible to the reality of communities located in areas difficult to reach in the Brazilian Western Amazonia, presents itself as an useful element for health care practices. However, the complexity of the healthillness process that involves infection with HBV and HDV, added to the peculiarities from the Amazon biome, requires a detailed description and analysis of multiple factors that are beyond the aspects addressed in this research, especially when the limitations inherent to the use of secondary data are considered, requiring new researches, with different guidelines, in order to find solid scientific evidence.

\section{REFERENCES}

1. Botelho-Souza LF, Vasconcelos MPA, Santos AO, Salcedo JMV, Vieira DS. Hepatitis delta: virological and clinical aspects. Virol J [Internet]. 2017 [cited 2017 Sep 19];14(1). Available from: http://virologyj.biomedcentral.com/articles/10.1186/s12985-017-0845-y

2. Fonseca JCF. Natural history of chronic hepatitis B. Rev Soc Bras Med Trop. 2007;40(6):672-7. doi: http://dx.doi.org/10.1590/ S0037-86822007000600015

3. Lampertico P, Agarwal K, Berg T, Buti M, Janssen HLA, Papatheodoridis G, et al. EASL 2017 Clinical Practice Guidelines on the management of hepatitis B virus infection. J Hepatol. 2017;67(2):370-98. doi: https://dx.doi.org/10.1016/j.jhep.2017.03.021

4. Lopes TGSL, Schinoni MI. General aspects of hepatitis B. Rev Ciênc Méd Biol. 2011;10(3):337-44. doi: http://dx.doi.org/10.9771/cmbio. v10i3.5899

5. Wedemeyer H, Manns MP. Epidemiology, pathogenesis and management of hepatitis D: update and challenges ahead. Nat Rev Gastroenterol Hepatol. 2010;7(1):31-40. doi: https://dx.doi.org/10.1038/nrgastro.2009.205

6. Liaw Y-F, Chu C-M. Hepatitis B virus infection. Lancet. 2009;373(9663):582-92. doi: https://dx.doi.org/10.1016/S0140-6736(09)60207-5

7. Seeger C, Mason WS. Molecular biology of hepatitis B virus infection. Virology. 2015;479-480:672-86. doi: https://dx.doi.org/10.1016/j. virol.2015.02.031

8. Alfaiate D, Dény P, Durantel D. Hepatitis delta virus: from biological and medical aspects to current and investigational therapeutic options. Antiviral Res. 2015;122:112-29. doi: https://dx.doi.org/10.1016/j.antiviral.2015.08.009

9. Oliveira MS, Valle SCN, Souza RM, Silva RPM, Figueiredo EN, Taminato M, et al. Scientific evidence on hepatitis Delta in Brazil: integrative literature review. Acta Paul Enferm. 2017;30(6):658-66. doi: http://dx.doi.org/10.1590/1982-0194201700091

10. Ministério da Saúde (BR). Clinical Protocol and Therapeutic Guidelines for Hepatitis B and Coinfections [Internet]. Ministério da Saúde; 2016[cited 2017 Sep 19]. Available from: http://www.aids.gov.br/tags/publicacoes/protocolo-clinico-e-diretrizes-terapeuticas

11. Burns GS, Thompson AJ. Viral Hepatitis B: Clinical and Epidemiological Characteristics. Cold Spring Harb Perspect Med. 2014;4(12):a024935a024935. doi: https://dx.doi.org/10.1101/cshperspect.a024935

12. Oliveira MS, Valle SDCN, Silva RPM, Figueiredo EN. Chronic hepatitis B and hepatitis D superinfection in patients in the brazilian Western Amazon. Rev Epidemiol Control Infec[Internet]. 2015 [cited 2016 Apr 17];5(2). Available from: http://online.unisc.br/seer/index.php/ epidemiologia/article/view/5442

13. Lin C-L, Kao J-H. New perspectives of biomarkers for the management of chronic hepatitis B. Clin Mol Hepatol. 2016;22(4):423-31. doi: https://dx.doi.org/10.3350/cmh.2016.0069

14. Confalonieri UEC. Saúde na Amazônia: um modelo conceitual para a análise de paisagens e doenças. Estud Av. 2005;19(53):221-36. doi: http://dx.doi.org/10.1590/S0103-40142005000100014 
15. Viana ALA, Machado CV, Baptista TWF, Lima LD, Mendonça MHM, Heimann LS, et al. Universal health systems and territory: challenges for a regional policy in the Brazilian Legal Amazon. Cad Saúde Pública. 2007;23(suppl 2):S117-31. doi: https://dx.doi.org/10.1590/ S0102-311X2007001400002

16. Paraná R, Kay A, Molinet F, Viana S, Silva LK, Salcedo JM, et al. HDV genotypes in the western brazilian Amazon region: a preliminary report. Am J Trop Med Hyg. 2006;75(3):475-9.

17. Scaglione SJ, Lok ASF. Effectiveness of Hepatitis B Treatment in Clinical Practice. Gastroenterology. 2012;142(6):1360-1368. doi: https:// dx.doi.org/10.1053/j.gastro.2012.01.044

18. Braga WSM. Hepatitis B and D virus infection within amerindians ethnic groups in the Brazilian Amazon: epidemiological aspects. Rev Soc Bras Med Trop. 2004;37(suppl 2):9-13. doi: https://doi.org/10.1016/j.antiviral.2015.08.009

19. Ghamari S, Alavian SM, Rizzetto M, Olivero A, Smedile A, Khedive A, et al. Prevalence of Hepatitis Delta Virus (HDV) Infection in Chronic Hepatitis B Patients with Unusual Clinical Pictures. Hepat Mon [Internet]. 2013[cited 2016 Apr 19];13(8). Available from: http://www. hepatmon.com/?page=article\&article_id=6731

20. McMahon BJ. The natural history of chronic hepatitis B virus infection. Hepatology. 2009;49(S5):S45-55. doi: https://dx.doi.org/10.1002/ hep.22898

21. Mumtaz K, Ahmed US, Memon S, Khawaja A, Usmani MT, Moatter T, et al. Virological and clinical characteristics of hepatitis delta virus in South Asia. Virol J. 2011;8(1):312. doi: https://dx.doi.org/10.1186/1743-422X-8-312

22. Oliveira MS, Silva RPM, Valle SCN, Figueiredo EN, Fram D. Chronic hepatitis B and D: prognosis according to Child-Pugh score. Rev Bras Enferm. 2017;70(5):1048-53. doi: http://dx.doi.org/10.1590/0034-7167-2016-0205

23. Terrault NA, Bzowej NH, Chang K-M, Hwang JP, Jonas MM, Murad MH. AASLD guidelines for treatment of chronic hepatitis B: Hepatology, Month 2015. Hepatology. 2016;63(1):261-83. doi: https://dx.doi.org/10.1002/hep.28156

24. Bessone F. Diagnóstico da Hepatite B. In: Focaccia R. Tratado de hepatites virais e doenças associadas. 3a Edição. São Paulo: Atheneu; 2013. 357-367 p.

25. Chen J, Xu CR, Xi M, Hu WW, Tang ZH, Zang GQ. Predictors of liver histological changes and a sustained virological response to peginterferon among chronic hepatitis B e antigen-positive patients with normal or minimally elevated alanine aminotransferase levels. J Viral Hepat. 2017;24(7):573-9. doi: https://dx.doi.org/10.1111/jvh.12679

26. Zhang Q, Guo X, Zhao S, Pang X, Wang Y, Zhang Y, et al. Prognostic performance of clinical indices and model scorings for acute-on-chronic liver failure: a study of 164 patients. Exp Ther Med. 2016;11(4):1348-54. doi: https://dx.doi.org/10.3892/etm.2016.3037

27. Nguyen LH, Chao D, Lim JK, Ayoub W, Nguyen MH. Histologic changes in liver tissue from patients with chronic hepatitis $b$ and minimal increases in levels of alanine aminotransferase: a meta-analysis and systematic review. Clin Gastroenterol Hepatol. 2014;12(8):1262-6. doi: https://dx.doi.org/10.1016/j.cgh.2013.11.038

28. Kamath PS, Kim WR. The model for end-stage liver disease (MELD). Hepatology. 2007;45(3):797-805. doi: https://dx.doi.org/10.1002/ hep. 21563 